\title{
River was the only source of PHC in Jiaozhou Bay in 1984
}

\author{
Dongfang Yang ${ }^{1,2,3, a}$, Fengyou Wang ${ }^{1,2}$, Sixi Zhu ${ }^{1,2}$, Mingzhong Long ${ }^{1,2}$ and \\ Xiuqin Yang ${ }^{1,2, b, c}$ \\ ${ }^{1}$ Research Center for Karst Wetland Ecology, Guizhou Minzu University, Guiyang 550025, China; \\ ${ }^{2}$ College of Chemistry and Environmental Science, Guizhou Minzu University, Guiyang 550025, \\ China; \\ ${ }^{3}$ North China Sea Environmental Monitoring Center, SOA, Qingdao 266033, China. \\ adfyang_dfyang@126.com; bcorresponding author; 'cfywang@163.com.cn.
}

Keywords: PHC; Distribution; Source; River; Jiaozhou Bay

\begin{abstract}
Based on investigation dada on petroleum hydrocarbon (PHC) in July, August and October 1984 in Jiaozhou Bay, we analyzed the content, distribution of PHC. Results showed that PHC contents in 1984 in surface waters were $0.01-0.16 \mathrm{mg} \mathrm{L}^{-1}$ and were meeting Grade I (0.05 mg $\mathrm{L}^{-1}$ ), II (0.05 $\mathrm{mg} \mathrm{L}^{-1}$ ) and III (0.30 $\left.\mathrm{mg} \mathrm{L}^{-1}\right)$ in National Sea Water Quality Standard (GB 3097-1997). We found that river was the only source of PHC. The source strengths of Haibo River and Loushan River were $0.6 \mathrm{mg} \mathrm{L}^{-1}$ and $0.05-0.16 \mathrm{mg} \mathrm{L}^{-1}$, respectively. In generally, this bay had been lightly polluted by PHC, and the source-control/reduction of PCH was necessary.
\end{abstract}

\section{Introduction}

A large amount of PCH-containing waste waters were generated and discharged rivers and marine bays along with the rapid increase of industry and agriculture, and the pollution in the environment could be harmful to human being itself finally. Hence, the research on the contents, pollution levels and sources of PHC in marine bay was essential to protect the marine environment and to maintain the harmonious development of society economy and ecological environment [1-5].

Jiaozhou Bay is located in Shandong province, eastern China, and had been polluted by various pollutants including PHC [1-5]. This paper analyzed the contents, pollution levels and sources of PHC based on investigation dada on PHC in July, August and October 1984 in Jiaozhou Bay. The Major purpose of this paper was to provide scientific background and basis for provide basis for pollution control and environmental remediation in marine Bay.

\section{Material and method}

Jiaozhou Bay $\left(35^{\circ} 55^{\prime}-36^{\circ} 18^{\prime} \mathrm{N}, 120^{\circ} 04^{\prime}-120^{\circ} 23^{\prime} \mathrm{E}\right)$ is a semi-closed bay located in the south of Shandong Province, eastern China (Fig. 1). The total area and bay mouth depth $446 \mathrm{~km}^{2}$ and $3 \mathrm{~km}$, respectively. The bay has more than ten inflow rivers, including Haibo Rriver, Licun Rriver and Loushan Rriver etc., all of which have seasonal features [6-7]. The data was provided by North China Sea Environmental Monitoring Center. The survey was conducted in July August and October 1982 (Fig. 1). PHC was sampled and monitored follow by National Specification for Marine Monitoring [8]. 


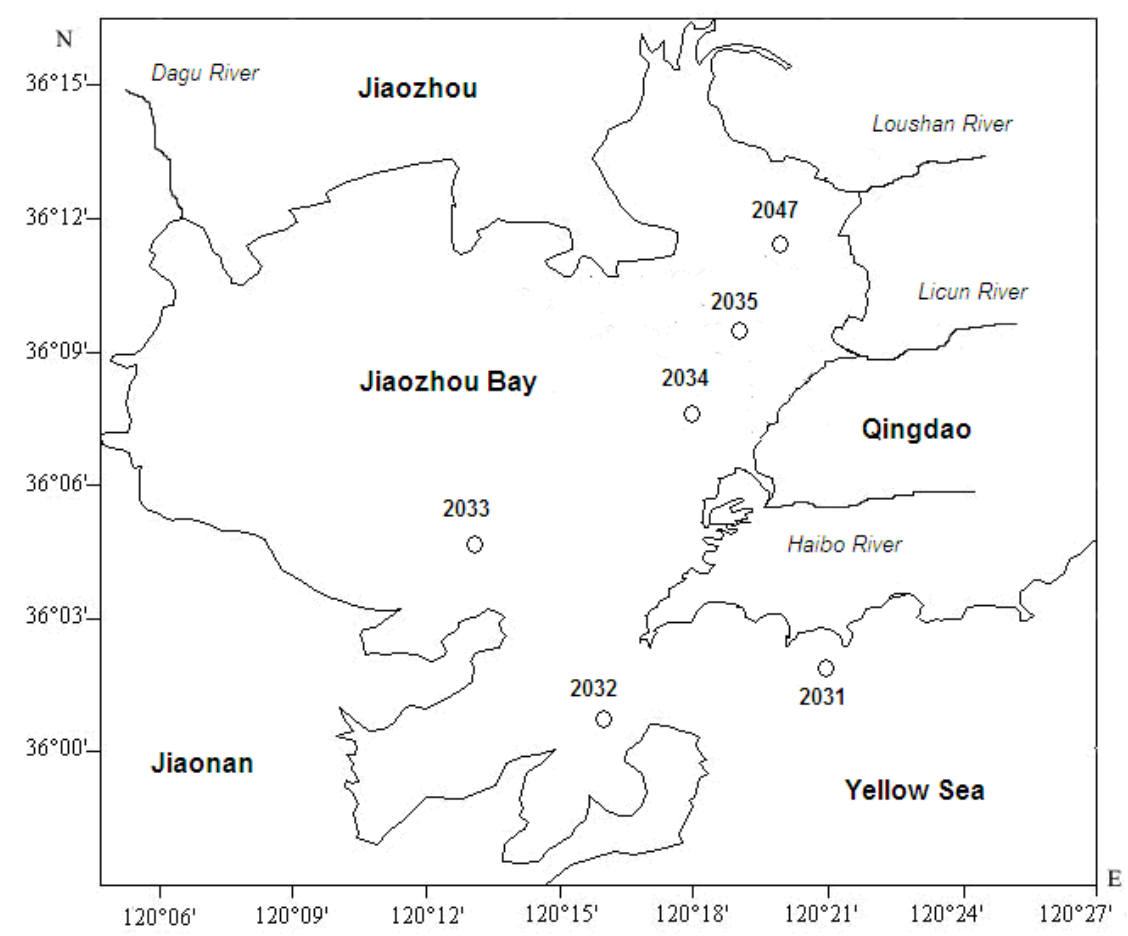

Fig.1 Investigation sites in Jiaozhou Bay

\section{Results and discussion}

Contents of PHC. As a whole, the contents of PHC in July, August and October in surface waters were $0.05-0.06 \mathrm{mg} \mathrm{L}^{-1}, 0.09-0.16 \mathrm{mg} \mathrm{L}^{-1}$ and $0.01-0.05 \mathrm{mg} \mathrm{L}^{-1}$, respectively. PHC contents in July and August were higher than Grade II $\left(0.05\right.$ mg. $\left.\mathrm{L}^{-1}\right)$ and meeting III $\left(0.30 \mathrm{mg} . \mathrm{L}^{-1}\right)$ in National Sea Water Quality Standard (GB 3097-1997), while in October were Grade I and II (Table 1).

Table1 Pollution level of PHC in July, August and October 1984

\begin{tabular}{|c|c|c|c|}
\hline Month & July & August & October \\
\hline Content/mg L ${ }^{-1}$ & $0.05-0.06$ & $0.09-0.16$ & $0.01-0.05$ \\
\hline Water quality grade & III & III & I and II \\
\hline
\end{tabular}

For detail, PHC contents in July were ranging from 0.05-0.06 $\mathrm{mg} \mathrm{L}^{-1}$, yet there was a divide in the estuary of Haibo River. PHC contents from the estuary of Haibo River to the northeast of the bay were $>0.05 \mathrm{mg} \mathrm{L}^{-1}$, and were belong to Grade III, while to the south were $<0.05 \mathrm{mg} \mathrm{L}^{-1}$ and were belong to Grade I and II. It could be found that waters in the estuary of Haibo River were slightly polluted by PHC in July, yet were not polluted in other locations. In generally, this bay bad been slightly polluted by PHC in 1984. For seasonal scale, the pollution levels of PHC were highest in August and were lowest in October, while for spatial scale were higher in the estuaries of the major rivers.

Horizontal distributions of PHC. In July, there was a high value $\left(0.06 \mathrm{mg} \mathrm{L}^{-1}\right)$ in Site 2034 and a high value region in the estuary of Haibo River, and there were a series of semi-concentric circles, which were decreasing from the high value center to the bay mouth and the outside of the bay mouth (0.05 $\left.\mathrm{mg} \mathrm{L}^{-1}\right)$ (Fig. 2). In August, there was a high value $\left(0.16 \mathrm{mg} \mathrm{L}^{-1}\right)$ in Site 2047 and a high value region in the estuary of Loushan River, and there were a series of semi-concentric circles, which were decreasing from the high value center to the bay mouth and the outside of the bay mouth $\left(0.09 \mathrm{mg} \mathrm{L}^{-1}\right)$. In October, there was a high value $\left(0.05 \mathrm{mg} \mathrm{L}^{-1}\right)$ in Site 2047 and a high value region in the estuary of Loushan River, and there were a series of semi-concentric circles, which were decreasing from the high value center to the bay mouth and the outside of the bay mouth $(0.01$ $\mathrm{mg} \mathrm{L}^{-1}$ ) (Fig. 3). The distributions of PHC were implying the sources and source strengths. 


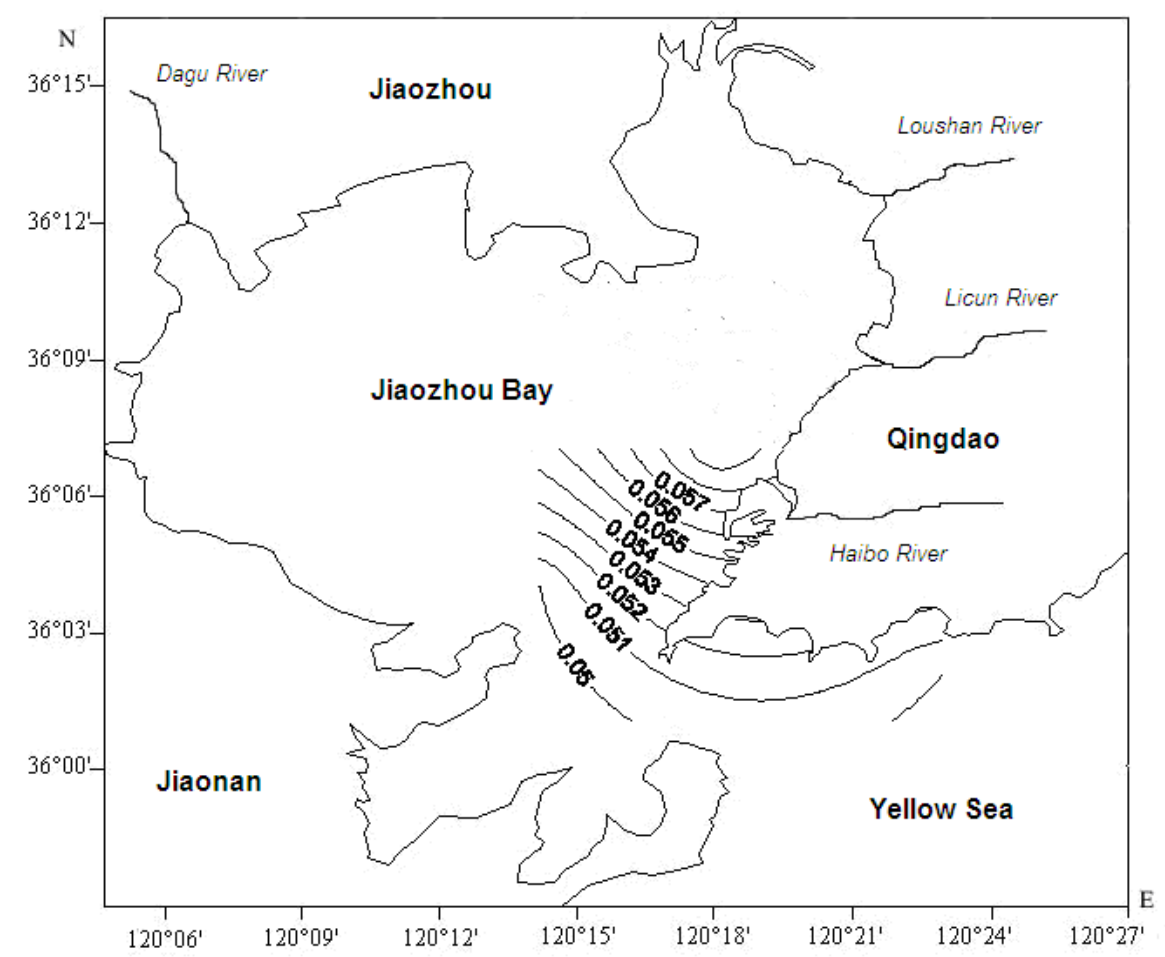

Fig. 2 Horizontal distributions of PHC in surface waters of Jiaozhou Bay in July 1984

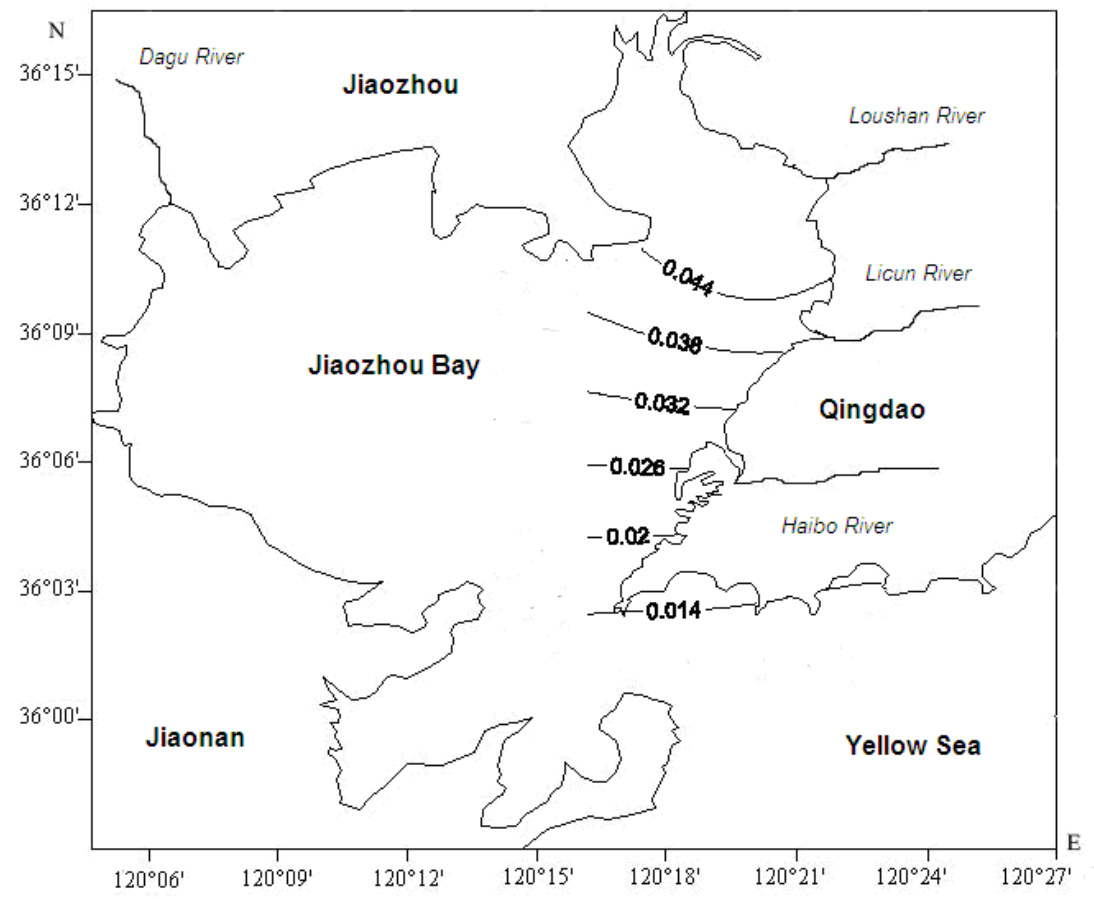

Fig. 3 Horizontal distributions of PHC in surface waters of Jiaozhou Bay in October 1984

Sources of PHC. There were high value region in the estuary of Haibo River in the northeast of the bay, indicating that the major source of PHC in July was Haibo River, whose source strength was $0.06 \mathrm{mg} \mathrm{L}^{-1}$. Moreover, the source strength was stable, due to the low value in the bay mouth far away from the high value center was still as high as $0.05 \mathrm{mg} \mathrm{L}^{-1}$. Similarly, it could be found that Loushan River was the major source of PHC in August, and the source strength was very high $\left(0.16 \mathrm{mg} \mathrm{L}^{-1}\right)$. Hence, PHC contents in August were ranging from 0.09-0.16 $\mathrm{mg} \mathrm{L}^{-1}$. There was also a high value region in the estuary of Loushan River in October, yet the source strength was relative weak $(0.05 \mathrm{mg} \mathrm{L}-1)$, resulting in the low contents in October (0.01-0.05 $\left.\mathrm{mg} \mathrm{L}^{-1}\right)$. Hence, it could be concluded that river flow was the major source of PHC in Jiaozhou Bay in 1984. The source 
strengths of Haibo River and Loushan River were $0.6 \mathrm{mg} \mathrm{L}^{-1}$ and $0.05-0.16 \mathrm{mg} \mathrm{L}^{-1}$, respectively (Table 2). The source strength of Loushan River was high than Haibo River, yet both of which were higher than Grade I and II and meeting III in National Sea Water Quality Standard (GB 3097-1997).

Table 2 Source and source strengths of PHC in Jiaozhou Bay in 1984

\begin{tabular}{|c|c|c|}
\hline Source & Haibo River & Loushan River \\
\hline Source strength/mg L ${ }^{-1}$ & 0.06 & $0.05-0.16$ \\
\hline Water quality grade & III & III \\
\hline
\end{tabular}

\section{Conclusion}

The contents of PHC in July, August and October in surface waters were $0.05-0.06 \mathrm{mg} \mathrm{L}^{-1}$, $0.09-0.16 \mathrm{mg} \mathrm{L}^{-1}$ and $0.01-0.05 \mathrm{mg} \mathrm{L}^{-1}$. For seasonal scale, the pollution levels of PHC were highest in August and were lowest in October, while for spatial scale were higher in the estuaries of the major rivers.River flow was the major source of PHC in Jiaozhou Bay in 1984. The source strengths of Haibo River and Loushan River were $0.6 \mathrm{mg} \mathrm{L}^{-1}$ and $0.05-0.16 \mathrm{mg} \mathrm{L}^{-1}$, respectively, both of which were meeting Grade III. In generally, this bay had been lightly polluted by PHC, and the source-control/reduction of PCH was necessary.

\section{Acknowledgement}

This research was sponsored by Doctoral Degree Construction Library of Guizhou Nationalities University, Education Ministry's New Century Excellent Talents Supporting Plan (NCET-12-0659), the China National Natural Science Foundation (31560107), Major Project of Science and Technology of Guizhou Provincial ([2004]6007-01), Guizhou R\&D Program for Social Development ([2014] 3036) and Research Projects of Guizhou Nationalities University ([2014]02), Research Projects of Guizhou Province Ministry of Education (KY [2014] 266), Research Projects of Guizhou Province Ministry of Science and Technology (LH [2014] 7376).

\section{References}

[1] Yang DF, Zhang YC, Zou J, et al.: Open Journal of Marine Science, vol. 2 (2011), p. 108-112

[2] Dongfang Yang, Peiyan Sun, Chen Chen, Hongyan Bai and Qing Zhou: Coastal Engineering, Vol. 32 (2013), p. 60- 72. (in Chinese)

[3] Yang DF, Sun PY, Ju L, et al.: Proceedings of the 2015 international symposium on computers and informatics, vol, (2015), p. 2647-2654.

[4] Yang DF, Wang FY, Zhu SX, et al.: Proceedings of the 2015 international symposium on computers and informatics, Vol. (2015), p. 2661-2666.

[5] Yang DF, Wu FYm He HZ, et al.: Proceedings of the 2015 international symposium on computers and informatics, Vol. (2015), p. 2647-2654.

[6] Yang DF, Chen Y, Gao ZH, et al.: Chinese Journal of OceanoLogy and LimnoLogy, Vol. 23(2005), p. 72-90.

[7] Yang DF, Wang F, Gao ZH, et al. Marine Science, Vol. 28 (2004), p. 71-74. (in Chinese)

[8] China's State Oceanic Administration: The specification for marine monitoring (Ocean Press, Beijiang 1991), p.1-300. (in Chinese) 